\title{
O PLURALISMO POLÍTICO E A REELEIÇÃO NA ÓTICA REPUBLICANA
}

\author{
Rafael Almeida Callegari ${ }^{1}$ \\ Direito Constitucional/Direitos Políticos
}

Palavras-Chave: Pluralismo, Democracia, Reeleição, Eleições Proporcionais

\section{Resumo}

O povo brasileiro, reunido através de seus representantes na Assembleia Nacional Constituinte, montou uma estrutura de atuação política visando $o$ aumento da representatividade, uma maior participação popular nas decisões políticas e buscou um aprimoramento na escolha de seus representantes. Tudo sobre a ótica de um alicerce do então novo Estado: o pluralismo político. A diversidade de opiniões, textos e contextos que norteiam a construção constitucional é maior quanto igualmente plúrime forem as vozes ouvidas no processo democrático. Resguardar tal pluralidade é essencial para a manutenção da sociedade, o equilíbrio entre a maioria e a minoria e o assegurar de seus direitos e intenções em benefício da Pátria. Dentre os mecanismos de exercício da política nacional, o instituto da reeleição é ora defendido, ora combalido, se fazendo necessária a análise deste sob o enfoque do fundamento da República alhures traçado.

\section{Introdução}

De tempos em tempos o brasileiro se depara com a discussão a respeito de haver ou não alguma vantagem na aplicação do instituto da reeleição, ora defendendo sob o prisma da liberdade de voto, ora atacando sob a ótica de falta de democracia real. O objetivo do presente trabalho é fazer uma leitura do tema e compreendê-los com enfoque restrito ao pluralismo político, através de um método de abordagem sistêmico e hermenêutico e um método de procedimento bibliográfico em doutrinas da área e correlatas, delimitando o tema e referencial teórico na intenção em consolidar o fundamento da república como elementar à vida democrática.

\section{Embasamento Teórico}

Em nada adianta possuir o direito fundamental à liberdade de expressão, de opinião e de convicção política se o Estado não vela respeito à pluralidade de expressões, opiniões e convicções. Norberto Bobbio traça que o pluralismo tem como intenção a formação de uma sociedade composta de vários centros de poder que, mesmo em conflito entre si, tenham como fiel a intenção de eliminar qualquer estrutura dominante e centralizada.

Natural então identificarmos tal espírito na Constituição da República promulgada em outubro de 1988 porque ela não somente é fruto de tal diversificação, constatada em sua formação e característica analítica, como também em razão do transpasse de conquistas políticas realizadas naquela década e que retiravam a Nação de um sistema dominante e ditatorial.

Para Miguel Reale, o pluralismo de ideias e convicções faz parte da natureza humana e está intimamente relacionada à liberdade do indivíduo, do que podemos direcionar a

Professor de Direito Constitucional da Faculdade Integrado de Campo Mourão - PR - Email: rafael.callegari@grupointegrado.br 
conclusão de que não seria diferente sua defesa como fundamento em uma sociedade dita por democrática.

A concepção inicial de pluralismo político decorre de três tipologias apresentadas por Jairo Marconi Nicolau, sendo a primeira a ideológica, consistente na função dos partidos em expressar diversas opiniões da sociedade; sociológica, onde os partidos servem como canalizadores de interesses segmentários e, por fim, a institucionalizada, em que a estrutura político-democrática (sistemas de eleição, governo, representação e estrutura estatal) são determinantes para construir o cenário de atuação dos partidos.

Reconhecida a importância da pluralidade política nacional, ainda mais em considerando as dimensões continentais do país e sua elevada estrutura pública (em especial a municipal), importa observar que a Constituição Federal embora tenha alçado o pluralismo político à fundamento da República, não fez maiores considerações em instrumentalizá-lo e garanti-lo salvo no que toca a liberdade no exercício do sufrágio e na divisão de sistemas de eleição em majoritário e proporcional, privilegiando a pluralidade partidária neste último sistema.

Contudo o pluralismo político não significa exclusivamente diversidades de partidos políticos. O sistema político brasileiro não se reduz à atividade partidária, nele se verificando em toda forma de atuação do indivíduo para com o Estado, através da iniciativa popular, das audiências públicas e outros instrumentos garantidores de maior participação democrática.

Desta forma o pluralismo político está igualmente na diversidade de representantes, ponto nevrálgico da discussão que ora se apresenta. A diversidade de ideias, concepções e intenções, buscando-se integrá-las na perseguição dos objetivos fundamentais da República é o maior mote do pluralismo político e não se trata de atividade exclusivamente partidária. Não há pluralismo sem os direitos fundamentais de reunião, expressão e convicção política, nem estes sem a força motriz daquele.

A reeleição é a possibilidade do indivíduo em concorrer ao mesmo cargo político que ocupa. A Constituição Brasileira, em seu artigo $14, \S 5^{\circ}$, limitava-se a proibir tal instituto aos integrantes do Poder Executivo, nada traçando em proibitivo aos integrantes do Poder Legislativo que possuem tal permissividade até os dias atuais.

Tal causa de inexigibilidade absoluta reconhecida pelo Supremo Tribunal Federal na Ação Direta de Inconstitucionalidade $\mathrm{n}^{\circ}$ 1.805, passou então a ser discutida pelo Poder Constituinte Derivado Reformador, o qual alterou aquele dispositivo constitucional, instalando a permissividade de uma única reeleição, através da Emenda Constitucional $\mathrm{n}^{\circ}$ $16 / 97$.

Gilmar Ferreira Mendes preleciona que o maior motivo para a alteração constitucional era o anseio em permitir a continuidade administrativa, doravante denominado de postulado, sendo essencial à regular representatividade política nacional.

No que toca à reeleição para cargos do Poder Executivo, a supra citada emenda constitucional cuidou de impor limite temporal em obediência ao Princípio Republicano, que impede a perpetuação de uma mesma pessoa ou grupo no poder.

E é justamente frente ao Princípio Republicano que surgem então críticas à reeleição de integrantes do Poder Legislativo. Considerando a necessidade de interpretar a Constituição de forma sistêmica, é flagrante que a mesma pretende a pluralidade de representação política, situação que não se verifica pela reeleição daqueles cargos.

Natália Souza Santos corrobora com a ideia ao assentir que o princípio republicano deve ser analisado de ótica distinta da mera formalidade de oposição à forma monárquica, cabendo observar que "possui íntima relação com o regime político republicano, que prevê que os seus agentes exerçam funções políticas em representação ao povo, devendo decidir em nome desse", e "se submeter no que toca à satisfação do interesse público, cumprindo o mandato que lhe é outorgado". 
Paulo Bonavides, ao considerar a atuação política e a representação da vontade do povo, detentor do poder, aduz que "a dialética democracia-representação atravessa agora a fase histórica mais aguda, em que os componentes plebiscitários se introduzem no organismo das instituições representativas e alteram o equilíbrio e o quadro das relações de poder entre o eleito e o eleitor".

E que não se diga que a reeleição existe por questão de vontade popular, manifestada pelo voto e correspondente desejo de que o candidato mantenha-se no cargo, nem em vontade efetivamente soberana nas eleições proporcionais, uma vez que é fato claro que não basta ao candidato o número de votos para assumir o cargo legisferante, como também precisa de que sua legenda obtenha a proporcionalidade necessária para o êxito.

\section{Conclusões}

O instituto da reeleição para os integrantes do Poder Legislativo deve ser analisado dentro de um enfoque sistêmico com o fundamento republicano do pluralismo político. Desta forma merece nova análise, em especial no que tange a ausência de limites definidos para a sua ocorrência.

A infeliz perpetuação de alguns integrantes nos cargos legisferantes caminha em sentido diametralmente oposto ao ensejo de temporariedade no exercício das funções do Estado, afastando a verdadeira representatividade buscada pelo pluralismo político e, igualmente, colocando em xeque a real representatividade da Soberania Popular.

Para que a República Federativa do Brasil possua efetiva força de Estado Democrático de Direito, impera a necessidade de pluralidade de representação em todas as esferas de Poder, em especial na legisferante, onde se identificarão os limites de atuação do Poder Executivo, pelo que se conclui pela necessidade de novo processo constitucional reformador, para fins de emendar a Lei Magna com a limitação temporal àqueles cargos.

\section{Referências}

BOBBIO, Norberto. O Futuro da Democracia: uma defesa das regras do jogo. Tradução de Marco Aurélio Noqueira. 5a ed. São Paulo: Paz e Terra, 1992.

BONAVIDES, Paulo. Ciência Política. 19ª ed. São Paulo: Malheiros, 2012.

MENDES, Gilmar Ferreira. Curso de Direito Constitucional. $8^{\mathrm{a}}$ ed. São Paulo: Saraiva, 2013.

NICOLAU, Jairo Marconi. Multipartidarismo e Democracias: o caso do Brasil. Tradução de Vera Pereira. Rio de Janeiro: Fundação Getúlio Vargas, 1996.

REALE, Miguel. Política e Direito: ensaios. $1^{a}$ ed. São Paulo: Saraiva, 2006.

SANTOS. Natália Souza. Princípio Republicano: um princípio fundamental em xeque frente a vontade popular. Centro de Pesquisa do Instituto de Direito Público. Disponível em: http://www.portaldeperiodicos.idp.edu.br/index.php/cadernovirtual/article/viewFile/638/437. Acesso em: 23 set. 2013. 